\title{
Politeness Strategy in Directive and Expressive Utterances as Found in Jane Eyre Movie
}

\author{
Yalmiadi $^{1, *}{ }^{*}$ Yossy Iddris ${ }^{2}$
}

\author{
${ }^{1}$ Dharma Andalas University. Padang. West Sumatera. \\ ${ }^{2}$ Eka Sakti University. Padang. West Sumatera. \\ *Corresponding author. Email: yalmiadi@unidha.ac.id
}

\begin{abstract}
This study discusses politeness strategies in directive and expressive speech, which are found in the Jane Eyre movie. The study is aimed at observing politeness strategies in conveying the intention or purpose of the speaker. The data are taken from the Jane Eyre movie. They are then collected through the observational method with note taking technique. The research sample consisted of 24 directive and expressive utterances containing politeness strategies. By using the theory proposed by Brown and Levinson about politeness strategies. Data are analyzed. From 24 dialogues, the writer found 33 data that contain politeness strategies. The results of the analysis are presented using the theory by Sudaryanto. The result of the data analysis shows that all kinds of politeness strategies occur in this movie. Based on the 24 dialogues studied, the writer finds that negative politeness strategies occur the most, namely 13 times, while positive politeness strategies occur 12 times, bald on record 4 times, and off record 5 times
\end{abstract}

Keywords: Politeness, Politeness Strategy, Directive Utterances, Jane Eyre movie

\section{INTRODUCTION}

Basically, the purposes of communication are to deliver idea, message and knowledge to others. Besides, it is also used to build and maintain a better social relationship in daily life. In our communication, however the chance to threat other people through the utterances is widely open. Sometimes, through the utterance the purpose of communication cannot be realized, instead miss understanding happens. The people also feel threaten because they feel disrespected and unappreciated. Consequently, the relationship will be broken. In order to build communicative purpose and good relationship, the speaker has to adjust his speech behavior. This is due to the people in society who have a face that should be accepted, and respected by other members. Goofman in Renkema (1993) specified that every participant in the social process has the need to be appreciated by others and the need to be free and not to be inferred with (p.31).

Being polite is a complicated business in any languages, because it depends on the context when the utterances take place. The utterances in one context may be considered polite but it may be considered impolite in other contexts. So, in order to keep the good relationship by being polite in society, the people should use certain strategies. Therefore, this research is conducted to investigate the important thing so employing politeness strategies in our daily life.

In this research the writer chooses the movie entitle Jane Eyre as the object to analyze politeness strategies, which is adopted from the novel Jane Eyre

written by Charlotte Bronte. This movie talks about the social living in $18 \mathrm{~h}$ century, in which the social status has a great influence in daily life. It is chosen because it has various communication aspects that are very relevant to be analyzed by using politeness strategy. Moreover, in Jane Eyre there are many conversations contain four types of politeness strategies.

\subsection{Identification of The Problem}

The research question to be answered in this research is: What are the types of politeness strategies used by participants in the movie from the view point of directive and expressive utterances? 


\subsection{Objective of the Study}

Basically, this research is aimed at finding out the types of politeness strategies that are used by the main character in the Jane Eyre movie.

\section{METHODS}

\subsection{The Method and Technique of Collecting the Data}

In this research, the writer uses non participants observational methods. It is applied in the process of collecting data. Spraedly (1980) in Stainback (1988, p.50) defines non-participatory observation as the lowest degree of involvement in observation. In other words, in taking data, the researcher does not involve in that situation. The data are observed by watching it for several times and $\mathrm{He}$ then chooses the directive and expressive utterance as data from the conversation. They are transcribed and classified as the utterances that contain politeness strategies.

However, in determining whether the utterances are required as politeness, the process is supported by the distributional Method (Haugen, 1951: Direction in Modern Linguistic in Sudaryanto, 1993: 15). Distributional method determines the data whether include as the research object. In addition, in collecting data, the analysis is continued by taking note of some information dealing with the research such as the context of utterances and other relevant information.

\subsection{The Method of Analyzing The Data}

The data are analyzed by using pragmatic perspective. The writer applies the theory of politeness proposed by Brown and Levinson (1987) to see the occurrences of politeness strategies, bald on record strategy, positive politeness strategy, negative politeness, off record and don't do FTA.

The next step is comprehended the data and the theory. It means that the data is supported by important element of the conversation analysis, especially pragmatic conversational analysis. The element is context.

\subsection{The Method of Presenting the Result of Analysis}

The data are not only presented on verbal form but also in nonverbal form. Moreover, non verbal communication is referring to analyses that use sign and symbol (Sudaryanto: 1993: p. 144). The data are described in natural language of analysis. The analysis is described by listing all sequences of the utterances during the movie's on, the analysis of politeness strategy in directive and expressive utterances.
Moreover, to support the presenting of the analysis the writer uses the theory of Sudaryanto (1993).

\section{RESULT AND DISCUSSION}

The Politeness Strategies used in Jane Eyre Movie

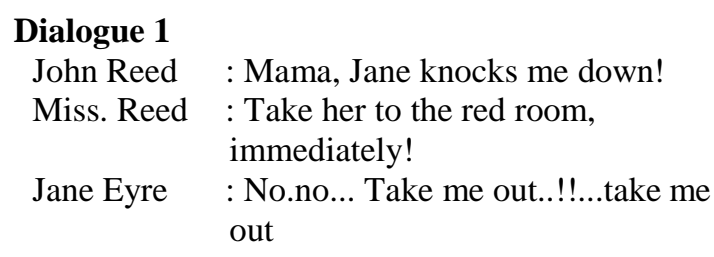

Jane is a ten years old girl who lives in her uncle's wife house. She has not had parents anymore since eight years ago because of an accident that makes them died. Although she lives with her aunt, she is always bullied and punished by John Reed, the only son of Miss Reed. John Reed has little enough affection for his mother and his sisters. It is afternoon; Jane reads the book in the dining room.

Suddenly, she hears John's Reed voice approaches the door, it makes her afraid and she chooses to hide behind the curtain, nevertheless it is useless because John finds her. John is angry and he speaks to her loudly, Jane feels she cannot stand being treated as animals again, when he grasps her hair and shoulders she gets the strength to treat back John cries and reports to Miss. Reed. Jane gets punishment by being locked in the red room, the place that she really hates. This room is the place that she really hates; being locked in this room makes her afraid and imagines the ghost of Mr. Reed. She knows this room is the place when Mr. Reed is lying before he put in the coffin. When the night comes, the room is very dark and she is just alone in this place. When she sees to the window, she sees a flash in front her. She screams and knocks the door in hoping someone listen to her screaming. No... no.. Take me out.!!.. No... no.. Take me out.!! She is very afraid and wants to go outside from this place. This sentence is a kind of request in the form of imperative act. The way she expresses her feeling is a kind of politeness strategy that is Bald on Record strategy. This is indicated by using imperative act, as Brown and Levinson said in their book "Politeness some universal in language usage"(1987) bald on record strategy can be seen in the imperative act.

\section{Dialogue 2}

Miss. Reed : This is the little girl I told you of Mr. Brocklehurst: She is very small. What is her age?

Miss. Reed : Ten years

Mr. Brocklehurst: So much, was the doubtful reply. what is your name? 
child?

Jane Eyre : Jane Eyre, sir

Mr. Brocklehurst: well, Jane Eyre and are you a good child?

One day the house has a guest, Mr. Brocklehurst. He is a chairman of an Orphanage school namely Lowood School. He is invited by Miss. Reed, Jane's Aunt to come and to take Jane to the school. She cannot tolerate the naughtiness of Jane anymore, so that she thinks to take Jane outside from her life by taking her to Orphanage school. It is nine o'clock in the morning Jane is told by Bessie that she Is invited to dining room. As she comes in, she looks up at tall straight black Figure stands in front of fireside. Miss Reed is in her usual seat by the fireside. She signs to Jane to some nearer and introduces Jane to him.

In opening the conversation, Mr. Brocklehurst tries to be polite in front of Jane. It is due to his goals come to this house in order to persuade Jane to live in Lowood School. Mr. Brocklehurst acts if he is a polite person in front of Jane, he Employs the following positive politeness strategy what is your name, child? This Utterance is categorized as a politeness strategy because the speaker uses the Identity of Marker, it is indicated by using the word child. The usage of identity of marker, the speaker wants Jane to appreciate and regard him as a good person. The use of identity marker child in his utterance to Jane is also one way to Minimize the distance between them, in order to make their communication later Become warm and can realize Miss. Reed'swill. The reasons to use this type Politeness strategy are to make Jane as the hearer feel being respected, being loved and so that she wants to go to Lowood school.

This kind of politeness strategy issued by $\mathrm{Mr}$. Brocklehurst to narrow the distance between them. Mr. Brocklehurst is a teacher; therefore, it is better for him to be polite to Jane in order to make their relation closer, and to attract her to go to that school. Moreover, the Children will respect the people who treat them well. This is a goal of speaker utterances.

\section{Dialogue 3}

Jane Eyre: I wish I would stay to one of these places, somewhere that so warm

Helen: I believe you will, but you have to work hard. You have to realize the fact our parents take us to this place to keep ourselves. If you took the profit you will go well. We will work hard and praise to god until we are going old

Jane Eyre: I think if we going adult, we will teach. What should we do go out from here?

Helen: We advertise

Jane is taken to Lowood School. This school is not as good as her imagination before. She imagines that in the school she will have many friends and people who love her. It due to Mr. Brocklehurst gives blacklist to Jane as a Wild and naughty girl. She only has one friend in this place, her name is Helen. The dialogues take place in Miss. Temple's room in Lowood School between Jane and Helen. Like as usual in Gates Hall, Jane likes reading and opens the picture of beautiful places in the book. She hopes one day she can stay or live in one of the places in the book, the places in which can keep she warm. She talks about the places and then she says Helen, I wish I would stay to one of this places. Helen Jane wats it so much and she knows why Jane has big desire for it. Jane is her friends, she doesn't want make Helen and therefore she tries to give respect and support Jane's desire. She convinces Jane that she will leave this school and living in her imaginary place by saying something optimistically.

She says I believe you will, but you have to work hard. By doing this strategy, Helen hopes what she is doing will be respected by Jane and can give spirit to Jane to be a good and patient child. Be optimistic is a strategy to employ positive politeness, in which by doing this strategy Helen wants to keep the positive face of Jane. As Brown and Levinson (1987) said positive politeness is redress and directed to the hearer's positive face

\section{Dialogue 4 \\ Jane : Here you are \\ Helen : "oh my god Jane, You must be cold, Jane. lie down and cover yourself with my quilt. \\ Jane : No, no Helen ...! You will not go anywhere}

The dialogue happens face to face between Jane and Helen in Miss. Temple's room. At the time Lowood School changes with the seasons. Typhus germs spread through the crowded school room and dormitory, until Lowood is more like hospital than a school. Starvation weakens the children. The fever spreads and at one time many children lays ill with typhus. Many children are sent to their home to be out of the area of infection and some of them are dead. Helen Also gets the ill and the doctor states that she will not survive anymore. She is Separated from other friends in order to avoid them from being infected.

In the cold night when all are a sleep and the dormitory is silent, Jane decides to go to Miss. Temple's room where Helen is kept. She sees Helen lies in the bed in weak condition. She approaches her and kisses her. Helen touches Jane, and she feels that Jane's body is cold, she says "oh my god, Jane, You must be cold, Jane. Lie down and cover ourself with my quilt. The expression of Helen toward Jane is classified as positive politeness strategy. Here, Helen uses strategy number one" notice, attend to Hearer interest, sympathy, need and good" It can indicate in Helen 
sentences that show her sympathy to Jane. Jane, your feet are bare. Lie down here and cover yourself with my guilt! The sentence is supported by the high intonation. The goal of the sentence is to make her body closer to her. The speaker of the sentence also uses address form as the instrument to show politeness. She calls the hearer with her name Jane, it indicates the speaker tries to minimize the distance between them.

\section{Dialogue 5}

Helen: "oh my god Jane, You must be cold, Jane. Lie down and cover yourself with my quilt. I will going to the god.

Jane: No, no Helen ... You will not go anywhere...

The dialogue happens face to face between Jane and Helen in Miss. Temple's room. At the time Lowood School changes with the seasons. Typhus Germs spread through the crowded school room and dormitory, until Lowood is more like hospital than a school. Starvation neglects and weakened the children. The fever spread and at one time many children lays ill with typhus. Many children are sent to their home to be out of infection and some of them are dead. Helen also gets the ill and she is punished by the doctor that she will not be here long, She is separated from other friends in order to avoid the other students getting infection from her.

One night, Jane cannot find Helen in her bedroom, she seeks in many places and the result she finds Helen in Miss Temple's room. Looking to Helen condition look so weak and listening to Helen voice so smooth, Jane thinks that she will leave her. Jane does not want it, she is the only friends that she has and the only people loves her in that school. Helen says that she is going to the God. Jane shocks listen to Helen, she does not want Helen leaves her alone. She expresses in high intonation No, no Helen

..! You will not go anywhere Helen.

The way she expresses her feeling to Helen is a kind of politeness strategy, that is Bald On Record Strategy. By doing this strategy Jane does not let Helen to leave her and keeps Helen stays and lives together with her. She does not try to minimize threats to the Helen's face.

In expressing her feelings, Jane also uses positive politeness strategy. It is indicated by using the address form. No, no Helen ...! In this sentence Helen is a kind of address. The using of the address from is kinds of deference. Using the deference is a strategy of positive politeness. Says the hearer's name in the utterance can be an indication that they have close relationship.

\author{
Dialogue 6 \\ Mrs. Fairlax: Oh god, Miss. Eyre. You must be \\ hungry. It must be long journey, How \\ long you have not sit in front of fireside \\ and has good meal, Jane? \\ Jane Eyre: Eight years! Mrs. \\ Fairlax: Oh...eight years
}

Jane's desire to get freedom from Lowood School becomes bigger and bigger. She needs new surrounding to refresh her mind. She feels that her world had bounded by rule and system of that school for eight years. She remembers Helen's utterance that she can make an advertisement if she wants to be out from that school. So, she decides to make an advertisement in local news for private teacher. One week later she gets a letter from Mrs. Fairlax, she invites her to be a private teacher for a thirteen years old girl in Thorn field Hall.

Jane throughs long Journey from Lowood to Thornfiled Hall, she looks tired. When she arrives in that place, she is welcomed by Mrs.Fairlax . She supplies Jane with delicious food, fresh water and fruit. Actually, Jane does not eat the good food for many years. Thus, she eats big portion of the food. Mrs. Fairlax is so surprises sees the way of Jane eat the food, she looks like a person Who hasn't eats for weeks. She says " oh god, Miss. Eyre. You must be hungry. It Must be long journey".

That utterance is a kind of sympathy given to Jane. The way she expresses Her feeling is by using exaggerating intonation and stress. This way indicates that the speaker considers positive face of the hearer by employing positive politeness strategy, Brown and Levinson states that positive politeness can employ by saying interest, approval and sympathy with hearer in exaggerating things. Here, Miss. Fairlax employs this strategy by sharpening her tone or intonation in the word Jane.

\section{Dialogue 7}

Adelle: $\quad$ you have a present for Miss. Eyre in your box, isn't it so?

Mr.Rochester : Who talks of presents? [...] did you expect a present Miss Eyre? Are you fond of presents?

Jane: I hardly know, sir. I have little experience of them

Mr.Rochester : Miss. Eyre, you are unlike Adelle, for this wild girl, French girl. The

Adelle: $\quad[.$. gift is her live. Right honey?

The participants are Mr. Rochester, Adele and Jane. At the time Mr. Rochester just comes from abroad, he wants acquaintance with his daughter's teacher. Thus, he invites Jane to have tea in drawing- room. They do some talking about him, Jane and also Adele. In the 
middle of conversation Adele asks Mr. Rochester if he also brings a present for Miss. Jane. Listen to the question Mr. Rochester asks back Jane whether Jane also fond of presents. He tries to compare Jane with his daughter who seeks for present if he comes from abroad and he has some talk with Jane about Adele, her daughter. The goal of their dialogue is used to give Jane explanation, why he always brings Jane present. Adele has been cared by Mr. Rochester since she was baby. He loves her very much, in order to show his love, he always tries to make Adele happy, one of them by giving her present after coming from abroad. From his statement we can indicate, there are two kinds of politeness strategy, positive politeness and off record.

Positive politeness can indicate by using the identity markers. Here, Mr. Rechester addresses his daughter with honey. The word honey is usually used by someone for her beloved person, it will make the communication between them become closer, because their relationship is daughter and father. Mr. Rochester says her daughter as a wild girl. Here, Wild girl means as a cheerful and active girl. The using of the word Wild girl, is a kind off record strategies. The factor of the speakers uses two kinds of types politeness strategy is the participants of dialogue, his beloved daughter.

\section{Dialogue 8 \\ Mr. Rochester: Miss. Eyre. Come here! Sit down please.. \\ Jane Eyre: $\quad$ I am sorry sir. I don't ask you permission read the book first \\ Mr. Rochester: Permission, for read the book? You thinking intelligent don't you? Why you need ask permission}

In the Thornfield Hall Jane still develops her hobbies reading and drawing. In this time Jane goes around in this home and then she finds a library. She opens the door and sees that are many book inside. She cannot stand to not read the book, so that she enters the room and reads some of the book.. When she enjoys reads the book suddenly $\mathrm{Mr}$. Rochester enters the room. Jane is so surprised to see Mr. Rochester cold face. She is instantly aware of her mistakes to not get the permission to read the book first.

Before Mr. Rochester says much words, Jane directly apologizes to him. She says Jam sorry sir, I don't ask you permission read the book first. Mr. Rochester just smile, actually he is not angry with Jane to read the books. Jane's sentence is classified as negative politeness because the way she expresses her feeling is a kind of apologize. By doing this strategy,
Jane regrets about her action that makes Mr. Rochester hurt. Instead of in the fact Mr. Rochester gives her pardoning. In saying her apologize, Jane also uses deference to addresses Mr. Rochester. She addresses the speaker or the owner of the house with Sir. By uttering sir, Jane shows her respect and appreciate to the hearer in which the owner of the Thornfiled Hall

\section{Dialogue 9}

Mr. Rochester: she left her in the parcel and labeled my name. I feed her in French and a few months ago I took her here. Tell me Jane, is there anything resembles me with Adele?

Jane Eyre: No, sir

Mr. Rochester: She is not my responsibility; I took as my own child. So, as your guide and master tell me it was right all things to do. Is it right?

Jane Eyre: $\quad$ yes sir

The situation of the dialogue is when Mr. Rochester, Adele and Jane take rest in the ground of Thornfield Garden in the afternoon. When Adele plays with her dog, Mr.Rochester and Jane talks about who Adele really is. He tells that Adele is a daughter of a French dancer, Celine Varens with whom he had once been love. The dancer ruins his love by running away with another man and leaves him a baby. She says she is his daughter, but that is not true. The last Mr. Rochester talks to Jane that he takes the child and gives her a home, hoping that French girl may grow up well in the English place. After talking long time, Mr. Rochester asks Jane's comment of what his doing right ar not. He says I gave her diamonds, clothes, servants and carriage. Is it okay of what I did Jane..? is it okay, right?. Here, Mr. Rochester addresses the teacher her child with her name Jane. This indicates that the speaker uses deference as negative politeness strategy to express his feeling; it happens because they do not have a close relationship each other. This dialogue intends to seek the agreement from Jane, he wants Jane to agree with his decision in looking after Adele. Seek agreement is a kind of positive politeness strategy. In which the speaker redress directed to hearer's positive face (Brown and Levinsoin :1987). Due to her status in the place as private teacher in Mr.Rochester place, Jane tries to show her agreement with Mr.Rochester by agreeing Mr. Rochester's utterances.

\section{Dialogue 10 \\ Jane Eyre : Sir! Mr. Rochester wake up!! Mr. Rochester :}

One night, Jane cannot sleep as usual, her nerves are tested unexpectedly. He hears a strange, cruel, low laugh sounded outside her door. It seems that a finger touches the handle of her doors and groups in the gallery outside. She opens door and there is a lighted 
candle outside her rooms, it is a strange thing. When she is looking at the right she smells a strong of smell burning. The smog comes from Mr. Rochester's room, instantly she goes inside, all else for gotten in sense of urgency. The curtains round the bed are on fire and beside that Mr. Rochester lies in the bed. Instantly she shouts at Mr. Rochester who is sleeping in the bed. Sir! Mr. Rochester wake up.!!.

The utterance of Jane is a kind of politeness strategy that is Bald on record strategy. It can indicate by the imperative act that Jane uses to wake up $\mathrm{Mr}$. Rochester. Although it kinds of imperative act, Jane also consider to use negative politeness strategy by using the deference that indicate with the word sir and Mr. By using this deference, she is still show her respect to the people she is talking to. From the explanation above I assume that the key of dialogue is serious, because it happens in emergency situation.

\section{Dialogue 11}

Mr. Ehnston: Face alike, skin alike and sound alike. You are one example of twin from one fetus. Would you permit me to ask some questions?

Twin ladies: sure, everything you need

The utterance above is an expressive utterance; it is a kind of request. It happens face to face between participants. At the time, Thornfield Hall held house party. The kitchen, the servant's Hall, the entrance Hall are equally alive and busy. There are many visitors spent their time in this place especially the people from high class such as Miss. Imingram's family. Among the visitors there is one person comes from abroad, his name Ehnston, he is Mr. Rochester's friends $\mathrm{n}$ he travels to West Indies. While party is holding, Mr. Ehnston sees twin ladies who are talking to other guests. He is interested with the ladies in the red Gown. He tries to approach them and knows their name. In order to express his feeling he employs negative politeness strategy Minimize imposition, $\mathrm{Mr}$. Ehnston savs 'if I allow, I want to know whether you.?' From the utterance, he pays attention to negative face of the addressee, the need to have freedom of imposition. Mr. Ehnston lets the ladies to choose their action, to answer or not answer his question. In this situation the ladies allow $\mathrm{Mr}$. Rochester to be acquainted with them.

\section{Dialogue 12}

Mr. Rochester: Here you are. Now, all guests have gone and situation back to usual. [...] What is that?

Jane Eyre: This is the book I used to read when child, I used to imagine one day I could go as I want. I bring it to Lowood School and now keeping this here

Mr. Rochester: Now, Miss Eyre, if I were lucky we might see dragonfly. I have ever talk to you about my journey to Blue Mounts in Mongolia and now you tell me your travel in the dark forest in your child memory

After all the guests have gone, Miss. Eyre comes to the library to put her old hook in the bookshelf. Mr. Rochester founds her inside and then he let's Jane to go outside, he says "Now, Miss Eyre, if I were lucky we might see dragonfly". Due to the speaker is the teacher of his child's, Mr. Rochester addressing her by using deference, it indicated by uttering Miss. Jane. This shows his respect and regard to the speaker. Mr. Rochester hopes he is lucky at the time to see dragonfly outside. When he utters that sentence Mr. Rochester also offers Jane to join with him, it indicates that by changing pronoun I and us, if I were lucky we might see dragonfly. He states if he is lucky not only him can see dragonfly, but also Jane. So, in this utterance, the speaker includes the hearer in his activity. In his statement Mr. Rochester hopes a kind feedback from Jane, because he ever tells Jane about his travel to Blue Mountain in Mongolia, and now he expects Jane to tell him about her travel in her child's memory.

So, from his utterance, the speaker employs two types of politeness; positive politeness and negative politeness. Positive politeness employed by asserting reciprocity and by including the hearer in his activity, this matter is intended to satisfy the negative face of hearer.

\section{Dialogue 13}

Georgy: Miss Eyre? You have not going tall? Jane Eyre: How Miss. Reed?

Georgy: Miss reed? Oh...you mean my mom. She is extremely sick and I doubt you can see tonight.

Jane Eyre: Would you step up stair and talks to her I have come? I would bless much to you.

The dialogue happens in Gateshead Hall between Jane and Georgy. At the time Jane receives a letter from Miss. Reed and she is unexpectedly invited to come. Mrs. Reed get a stroke, distraught by the death of her beloved son, and by the awful disclosures of her debt and loose living, In this time Miss. Reed will tell her about something that she hides for many years about Jane.

When she comes to the house she meets Georgy, the daughter of Miss. Reed who tidies up her gaunt in front of mirror. She is surprises sees Jane come to this house. Jane asks her how Miss. Reed was..,. Georgy says miss Reed.. Oh...you mean my mom. She asks back whether Jane points to her mother or not. The way she utters her feeling is a kind of positive politeness, in which she 
seeks the agreement to Jane that she asks her mother or not. It due to Jane has long time not come to the house even less asks about how Miss. Reed is. Georgy's utterance is indicated as seek agreement because in her utterance happen a repetition, as Brown and Levinson say in the book Politeness - some universal in language usage (1987) Seek Agreement can be employed in two ways safe topic and repetition. In the dialogue above, the speaker uses repetition to show that she is seeking for agreement.

In her sentence the speaker seems pessimistic that Jane can see Miss. Reed tonight, she says I doubt you can see tonight. This sentence is classified as negative politeness in which the speaker tries to satisfy Jane's negative face by saving a pessimistic utterance. The speaker employs this strategy because she wants Jane not to be disappointed when meeting Miss. Reed.

\section{Dialogue 14 \\ Georgy: Miss Eyre? You have not going tall? \\ Jane Eyre: How Miss. Reed? \\ Georgy: $\quad$ Miss reed? Oh...you mean my mom. She is extremely sick and I doubt you can see tonight. \\ Jane Eyre: $\quad$ Would you step up the stair and talks to her I have came?[...]! would bless much to you.}

The dialogue happens in Gateshead Hall between Jane and Georgy. At the time Jane receives a letter from Miss. Reed, and she is unexpectedly invited to come. Mrs. Reed has a stroke, distraught by the death of her beloved son, and by the awful disclosures of her debt and loose living. In this time Miss. Reed will tell her about something that she hides for many years about Jane. When she comes to the house she meets Georgy, the daughter of Miss. Reed who is tiding up her gaunt in front of mirror. She asks Georgy to talk to Miss. Reed that she has come in. She says Would you step up stair and talks to her I have came? [...] I would bless much to you. In this utterance the speaker employs negative politeness by using two strategies.

Firstly, the speaker uses strategy of negative politeness by minimizing imposition to the hearer. Here, Jane minimizes her imposition to Georgy to talk to her mother that she has come by uttering Would you step up stair and talks to her I have came?. I conclude that Jane uses this strategy in order to make Georgy does not feel forced by Jane. So, she says in polite way to Georgy. Secondly, in this sentence the speaker also goes on record as incurring a debt. It indicates that in the sentence I would bless much to you Jane explicitly confesses her debt to the hearer or Georgy if Georgy does what she wants. It means Jane will say thanks much if Georgy can talk to her mother that she has come in.

\section{Dialogue15 \\ Miss Reed : How is that? \\ Jane Eyre : This I am, Jane Eyre, You ask me to come \\ Miss. Reed: Yes, you know I am sick and I want to lighten my mind before I am dying. You know I had done twice wrong to you. I break my promise to my husband to feed you as my own child. You know it? \\ Jane: $\quad$ silent \\ Miss Reed : and Go to my dressing table and bring me the letter you will find inside!}

Jane is picked up by Bessie to Miss. Reed's room. She enters the room and sees Miss. Reed lies on the bed in the weak condition. She approaches her, and then Miss. Reed asks her name, but Miss. Reed does not believe she is Jane, the naughty child whom she is really hates for years ago. She says to Jane that she has done two wrong things to Jane which she now regrets about Once in breaking her promise to her husband that she will take care of Jane as if she is her own child. The second, she hides the fact that Jane has another living family until now. Miss, Reed tells Jane about her first mistake but for the second mistake she lets Jane to take the letter from her case. She says "Go to that case, and bring me the letter you will find inside!". According to Brown Levinson theory (1987), this utterance is classified as Bald on record strategy, because it is kind of imperative act in which employed in direct statement. As Brown and Levinson said, Bald on record strategy speaker wants to do FTA with maximum efficiency, rather than satisfy the here's face even to any degree (1987).

\section{Dialogue 16}

Miss. Reed

John Eyre :Madam, would you have the goodness send me the address of my nice, Jane Eyre

Jane takes the letter from a case of dressing table and then she is asked by Miss Reed to read the letter. She reads the letter carefully and knows that the letter comes from her uncle, John Eyre. She is so surprise that she has an uncle because she never knows she has an uncle before. Actually, the letter is dated three years ago, when she is still in Lowood School but Miss. Reed insists not to tell Jane.

The instrument of this dialogue is letter. The letter contains a request from John Eyre to Miss Reed. John needs the address of Jane because he is unmarried people and childless, he wants adopt Jane and inherit his heritage when he is died. In order to express his intention and realize his goal through this letter, the speaker says "would you have the goodness send me the address of my nice, Jane Eyre.," Here, John Eyre gives her a choice to send him the address of Jane or by 
minimizing his imposition to Miss. Reed. It is indicated by using the word would you. This utterance shows the speaker employs negative politeness strategy. minimize imposition Rx. The result, Miss. Reed not choose to realize his request instead of takes her revenge by writing them a letter that is explain Jane was dead by typhus fever at Lowood school, In this letter, the speaker also employs strategy number five: Give Deference, it is indicated by using the word Madam. The difference is addressed to Miss. Reed, this one of negative strategy in which the speaker tries to satisfy reader's negative face. The using of deference is also used to show his respect and appreciated to the reader or Miss. Reed.

\section{Dialogue 17}

Jane Eyre: This is written three years ago. Why you did not ever tell me I have an uncle who is still alive?

Miss Red: because I really hate you too much, I cannot forgive you

Jane: $\quad$ forgive me.

Miss reed: Your furry, I keep you but you treat me crime and you talk to me like wild animals.

Jane Eyre: Forgive me of my passionate nature. I was child aunt

Jane takes the letter and reads it carefully. After read the letter Jane sees the date of the letter. The date shows that it is sent to Miss. Reed three years ago. Jane shocks and talks to Miss, Reed Why did you never tell me I have an uncle who is still alive?. Jane asks the reason to Miss. Reed why she does not talk her 1 the letter three years ago. Besides, she also wants to know the fact of her behind it. From the utterances, the writer can conclude that the speaker uses positive politeness. The speaker of the dialogue asks the reason to hearer why she is doing Such thing to her. Ask the reason is a kind of positive politeness strategy in which the speaker redress to positive face of hearer. Here, Jane hopes her question will be answered by Miss. Reed., why she is not never talk to her about the fact

\section{Dialogue 18}

Jane Eyre: This is written three years ago. Why you did not ever tell me I have an uncle who is still alive?

Miss Red: because I really hate you too much, I cannot forgive you

Jaane: forgive me??

Miss reed: Your furry, I keep you but you treat me crime and you talk to me like wild animals.

Jane Eyre: Forgive me of my passionate nature. I was child aunt

Jane asks Miss. Reed's reason why she is never talks her about her uncle and the letter that has been sent three years ago. Miss. Reed says that she is really hate Jane very much and she cannot forgive her. Jane does not know why she cannot be forgiven by Miss. Reed, so that she asks the reason again. Miss. Reed says her reason why she hates Jane very much, so she says that " Your furry, I keep you but you treat me crime and you talk to me like wild animals" The utterance shows Miss. Reed gives the reason why she does that things to Jane. Gives the reason is one strategy to employ positive politeness.

By employing his type the speaker can keeps her positive face, she wants what they does appreciate by Jane. Beside positive politeness strategy, in the dialogue also contains off record strategy in Miss. Reed's utterance. In this utterance we can see that Miss. Reed uses metaphorical sentence, she talks something different with it really means. Here, we can see metaphorical sentence in the word...like wild animals. Actually, Miss. Reed wants talk the really behavior of Jane but in order to make it polite, she compares Jane's behavior with animals. The meaning of the wild animals here is talk in rush, behave not in good manner and naughty.

\begin{tabular}{|c|c|}
\hline \multicolumn{2}{|l|}{ Dialogue 19} \\
\hline Brigg: & $\begin{array}{l}\text { This marriage can't be continuing. } \\
\text { I oppose that. }\end{array}$ \\
\hline Mr. Rochester: & Who are you? \\
\hline Brigg: & My name is Brigg and I am a lawyer \\
\hline Rochester: & and you brave say me has a wife \\
\hline Brigg: & $\begin{array}{l}\text { I just try to tell you sir her } \\
\text { existences, with the law recognize } \\
\text { it. If you don't, }\end{array}$ \\
\hline Rochester & I have no wife... \\
\hline
\end{tabular}

The dialogue happens in the church between $\mathrm{Mr}$. Rochester and a lawyer of his last wife in their marriage day. When Mr. Rochester will say his vow in front of clergy men, someone disturbs their marriage and canceled it. The man savs that their marriage cannot be continued, because Mr. Rochester still has wife. $\mathrm{Mr}$ Rochester does not admit that, he is still tries to argue the fact and ask for the evidence. However, the lawyer has a law recognition of that, he says I just try to tell you sir her existence. Although the dialogue happens in the serious situation exactly in the tight situation, the lawyer still considers the face of Mr. Rochester by addresses $\mathrm{Mr}$. Rochester with sir.

In the theory of politeness strategy, the using of is one kind of negative politeness, in which the speaker gives deference to whom he is talking to. The using of sir indicates that the lawyer is still respect Mr. Rochester, In order to make his sentence become strong, Brigg uses ellipsis in his statement. her

exitances, with the law recognize it. If you don't. 
Actually, the sentence is ellipsis from his statement before if you don't recognize it. The use of ellipsis is a strategy of off the Record, in which the speaker hanging his sentence in the air. The end of this dialogue is to cancel the marriage, because Bridge still has a wife.

\section{Dialogue 20}

Rochester: Jane? Forgive me, I can't tell you Jane:

The dialogue happens in serious situation between Jane and Mr. Rochester in front of Jane's room. Jane's marriage is cancelled, because Mr. Rochester still has a wife. Although his wife is a mad girl, he never talks to Jane before. In the time they will utter the marriage vow in front of clergyman. Mr. Mason and his lawyer come and stop the marriage. Mr. Rochester lets them come to his house and reveal the fact to Jane and the others. He allows them to the room in the top of Thornfield Hall, the place where his wife is kept because she has going crazy for years. Jane feels hurt knows the fact, she is disappointed by Mr. Rochester. She runs to her bedroom, locks herself and crying inside. She feels her life, her dream and desire to leave happily with her love destroys. Mr. Rochester feels that he breaks Jane's heart and her dream. He comes to apologize to Jane, but she still never opens her door. Forgive me, I can't tell you. Apologize is one of the ways employ politeness strategy. It is categorized as negative politeness.

By doing this technique, speaker shows his regret toward the utterance that makes hearer hurt. Through the utterance the speaker tries to satisfying hearer's negative face. He tries to minimize his imposition to Jane and give the freedom to her to choose her action.

\section{Dialogue 21 \\ Servant: oh god miss Eliot, you look a ghost, here sit down. You look so weak, think you will melt in the fire place \\ Jane Eyre: I like fire}

After her marriage broken, Jane leaves Thornfiled Hall. Some one finds her dying in the meadow of the Hill. Jane faint for long days, when she gets up she cannot remember clearly who herself is. After some hours, Jane cannot be found in the bedroom. The house's servant finds her stand in front of fire place. When she finds Jane in front of the fireside, she notices to hearer hearer's condition by saying "oh god miss Eliot, you look a ghost, here sit down. you look so weak, think you well melt in the fire place". Utter this utterance it indicates the Interest, good and condition. In her utterances, the servant also employs off Speaker employs positive politeness strategy. Here she notices, attends to hearer and by using metaphors to state Jane's condition

She uses metaphors to state ug's condition in white and cold skin by comparing her with a Ghost. The speaker believes that, Ghost has white and cold skin. Beside that, the servant also uses metaphors to state Jane's body in weak condition will be melt. you look so weak, think you will melt in the fire place. Here, melt can be defined as fall down and faint. Using metaphor is a kind of off record strategy. As Brown and Levinson stated (1987: p.211) using off record strategy the speaker wants to employ an FTA, but wants to avoid the responsibility for doing it, he can perform it off record and let the hearer decide how to interpret it.

In expressing her sympathy the servant also addresses the hearer with her name. She uses deference to show her respect to hearer. Miss Eliot. In this servant's utterance, there is another politeness strategy occurs, it can indicated by using the deference

\section{Dialogue 22 \\ Miss. Oliver : Good morning Carlo.[...] Your dog is quickly recognize a friends than you are sir \\ St. John: Lovely evening Miss. Oliver, it is very late to you be out alone... \\ Miss Oliver: My father said you never come see he is now, he is alone this night and not very well. Would you come back with Me.? \\ St. John: it is not a proper time to disturb $\mathrm{Mr}$. Oliver}

The participants of this dialog are St. John and Miss Oliver. St. John is a clergyman who finds Jane in fainted condition in the meadow top of the hill and he is also the cousin of Jane. Miss. Oliver is the lady who falls in love with him and she lives near with his home. The dialog happens face to face in the evening the meadow, at the time Mr. River, Jane and his sister take a pleasure trip nether, $\mathrm{He}$ meets Miss. Oliver, the girl who lives in Vale Hills walking alone. He does some conversation and the last she invites St. John to come to her house are her father because her father need him. She says would you come back with me?

The way of Miss. Oliver invites St. John is kinds of politeness strategy. She tries to minimize her imposition by saying in polite way. The utterance of Miss. Oliver is one of a strategy of negative politeness. Here, the speaker gives freedom to a hearer to decide what his choice is. I assume that the ends of their utterance are just for to keep their relationship in which their relation have been distantly spaced since St. John refused her love. By using this strategy, Miss. Oliver satisfying St. John's negative face. She gives chance to him to choose his action, to accept her request or not. In that time, St. 
John refuses Miss Oliver invitation.

\author{
Dialogue 23 \\ Mr. Rochester : Who is there ? \\ Jane Eyre: $\quad[\ldots]$ silent \\ Mr. Rochester : I know these fingers, Jane. This is \\ you...? Isn't it? \\ Jane Eyre: $\quad$ Yes sir.
}

One year later, Jane knows the fact that she is the cousin of St. John St John's mother is the sister of her father. St. John invites her to do missionary to south of Africa but they should marry first, but Jane refuses the invitation and she decides to come back to Thornfield Hall. When she is coming the situation at the time has change, Mr. Rochester does not still live in Thornfiled hall because it has burnt by his crazy wife. He lives alone in other place. Due to the fire Mr. Rochester cannot see anything and become blind. He just can identify someone from their voice. This dialogue occurs in the moment of Jane serves him a cup of coffee. Suddenly Mr. Rochester touches Jane's hand. He thinks he knows the smooth finger, it is Jane's. He says I know these fingers, Jane. This is you...? Isn't it?. from this statement Mr. Rochester tries to convince himself that finger is Jane's. The utterance of Mr. Rochester is kinds of positive politeness, because he employs seek the agreement strategy when talking to Jane. Seek agreement is one strategy to redress positive face of hearer that they need to claim and appreciate. By employing this type, the speaker tries to minimize the distance between them.

\section{CONCLUSION}

Having analyzed all the data, the writer concludes that politeness strategies are important in communication. Those strategies keep the people's face in communication from Face Threatening Acts (FTA). The result of analysis shows that all types of politeness strategies occur in this movie, bald on record, positive politeness, negative politeness, off record and don't do FTA. All types can be seen in directive and expressive utterances. Generally, the characters in this movie use the strategy of politeness because they take consideration to the contexts of the utterances. Mostly, the dialogues in this movie are face to face communications and they know each others. Based on 24 dialogues the writer reveals that the strategy of negative politeness is dominant in this movie, it occurs 13 times. It is caused by the character's low social status in the conversation. While positive politeness happens 12 times, bald on record 4 times, and off record 5 times.

\section{AUTHORS' CONTRIBUTIONS}

Yalmiadi and Yossi Iddris carried out the study hand in hand. Yalmiadi came up with the idea of the study and simultaneously wrote and conducted the study with the help and support from Yossi Iddris who then contributed in finalizing the end result of this article to be published.

\section{ACKNOWLEDGMENTS}

The writer's deepest gratitude goes to all parties involved in accomplishing this article especially to RISTEKDIKTI and LPPM of Universitas Dharma Andalas (UNIDHA) for all support provided to the writer. He/She does realize that this research needs to be developed for better outcome; therefore, critics and suggestions from any parties are welcomed. The writer hopes that the outcome of this research will be beneficial and meaningful for both the readers and the writer himself.

\section{REFERENCES}

[1] Austin, J. L.1962. How to Do Things with Words. Cambridge. Mass: Harvard U.P

[2] Brown, P, \& Levinson, S. C.. Politeness: Some Universals in Language Usage. New York, NY: Cambridge University Press. 1987.

[3] Caplan, S. E \& Samter W. Communication

Ouarterly. University Park: Summer. Vol. 47, Iss. 3; pg. 245, 20 pgs. Politeness in Journal, Retrieved 2009, from http://www.proquest. 1999.

[4] Goffman, E. Interaction ritual: Essays on face- toface behavior. Garden City, NY: Doubleday \& Company, Inc. 1967

[5] Goldsmith, D. J., \& Parks, M. R. Communication Strategies for Managing the Risks of Seeking Social Support. S. Duck (Ed.), Personal relationships and social support (pp. 104-121). London: Sage. 1990.

[6] Hidayat, F. Politeness Strategy in Religious Debate: is the Bible God's Word. Padang: Unpublished (under graduated). Andalas University. 2007.

[7] Halliday, M.A. K and Hassan R. Language, Context and Text: Aspects Language in a Social-Semiotic Perspective. Deakin Univesity Press. 1985.

[8] Hinck, E. A \& Hinck, S.S. Argumentation and Advocacy. River Falls: Spring. Vol. 38, Iss. 4; pg. 234, 17 pgs. Politeness in Journal, Retrieved 2009, from http://www.proquest. 2002.

[9] Hinck, E. A., \& Hinck, S. S. Perot versus Gore: Politeness strategies in the NAFTA debate. Paper. April, 1995.

[10] Holmes. J. An Introduction to Sociolinguistic. New 
Jersey: Longman Publishing. 1992.

[11] Hornby, AS. Oxford Advanced Learner's Dictionary of Current English. Ed Sally Wehmeier. Oxford: Oxford University Press. 2005.

[12] Leech. G. Principles of Pragmatics. New Jersey: Longman Ltd, 1983.

[13] Mey, J. L. Pragmatics: An Introduction. Massachusetts: Blackwell publisher Inc. 2001.

[14] Reinkema, J. Discourse Studies: An Introductory TextBook. Amsterdam: John Benjamin Publishing Company. 1993.

[15] Spreadly. J. Research Design: Qualitative, Quantitativeand Mix Method Approaches. New York: Longman In Stainback, S andStaninback W. (2003). Understanding \& Conducting Qualitative Research. lowa: Kendall/HuntPublishing Company. 1994.

[16] Sudaryanto. Metode dan Aneka Teknik Analisis Bahasa: Pengantar Penelitian Wahana Kebudayaan secara Linguistis.Yogya: Duta Wacana UniversityPress. 1993.

[17] Yule, G. (1996). Pragmatics. Oxford: Oxford University Press. 1996. 